Part III

Charting the future: innovation, state power and the market system

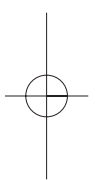


CHAPTER 11 15/2/06 2:25 PM Page 2

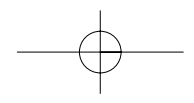




\section{Galbraith and the political economy of technological innovation: critical perspectives and a heterodox synthesis}

\section{Jerry Courvisanos}

\section{INTRODUCTION}

In The New Industrial State (NIS), Galbraith (1967) develops a unique approach to understanding the management of technological innovation. It is based on a critical evaluation of the decision-making processes of economic agents within institutions and how they react to the different levels of political power in society. This political economy (PE) approach to technological innovation is the overriding theme of this chapter and is in direct contrast to the plethora of books and articles that provide a technocratic approach to managing technological innovation. ${ }^{1}$ There has been an appalling lack of any $\mathrm{PE}$ analysis of technological innovation in the spirit of Galbraith since NIS. Kingston (1984) is one notable excellent exception. The extremely poor level of citation of the Kingston book in the twenty years after its publication is a reflection not of the quality of the work, but with the obsession with technocratic issues within the business management discipline. In the meantime, mainstream neoclassical economics refuses to look inside what Rosenberg calls 'the black box' of technological innovation despite all economists recognising the crucial role that it plays in economic development. ${ }^{2}$

Technological innovation has many definitions in the innovation literature. For the purposes of this chapter, the following is most appropriate: The creation, development and implementation of an idea from problem-solving or opportunity identification that alters (innovation) the current state of theoretical and practical knowledge, skills and artefacts in the production and delivery of economic activity (technology). Technology here refers to any production and delivery processes that require a significant input of fixed capital investment. ${ }^{3}$ In the context of innovation, technology matters because it is the engine that drives change and economic growth. This is in response to society's needs or in the conceiving of new economic opportunities that 
induce demand. Without effective demand generating the commercialisation of new technology, the idea remains merely an invention without exploitation.

Underlying the incessant drive in capitalism to technological change, are the agency processes of technological innovation that bring about this change. These agency processes needed to be clearly understood and appreciated for policy relevance to the public, private and third (non-profit) sectors. The scholarly works related to technological innovation have many ideological and functional intentions, leading to diverse perspectives on agency that have little in the way of overlap and even less dialogue between them. The PE approach in this chapter will provide a set of common evaluating criteria to assess critically all the perspectives.

A political economy approach that initiates this investigation is set out first, along with the evaluating criteria. Then the role of technological innovation in capitalism from the pro-market perspectives (neoclassical and neo-Austrian) establishes the historical basis of the individual capitalist-entrepreneur agent effecting change. Galbraith provides a critical response from which to appreciate the development of large corporate agency in technological innovation. This critical response comes from three perspectives that have adopted some aspects of Galbraith's NIS - institutionalists, resource-based strategists and post-Keynesians. The various perspectives are briefly outlined and critically assessed on the basis of the evaluating criteria. The final section identifies key common themes that exist across the perspectives outlined and proposes a heterodox synthesis that unifies these common themes around a Galbriathian framework of analysis.

\section{POLITICAL ECONOMY APPROACH}

The parameter that sets up this PE approach is the dynamic model of technological change based on Marx's laws of motion. Essentially, the circulation process under capitalism must overcome the limits of production by expanding over the barriers of declining additions to surplus value time (Lallier 1989). This determines the drive to technological innovation in three forms: (1) opening up new markets, (2) creating new needs and demands, (3) investment in increasingly technologically efficient means of production. These forms are endogenously linked to instability, unemployment, inequality and unsustainable development that create an economy with fundamental uncertainty. In fact, it is the attempt to 'control' this uncertainty that drives all the perspectives. This control comes from the agents that are given power in their respective perspectives (be it capitalists, entrepreneurs, technostructure, firm, creative elite or politicians). 
Crucially, the economic agents of institutions are the central decisionmaking actors in the process of technological innovation. These agents have the power to affect the way society adapts to such innovations in three ways: (1) ability to determine the nature of the technology employed; (2) monopoly power that resides with the entrepreneurs who install the innovation that can stifle other innovations as well as promote their own, (3) force society through organisational (politics), property (rights) and individual (charisma) elements to adopt the innovations they promote. This power view of innovation has two dimensions. One is the power to manipulate production in a way that technological innovation alters the physical aspect of the economy. Adam Smith, followed by Ricardo and Marx, developed this dimension around specialisation (Smith), employment (Ricardo) and exploitation (Marx) on the basis of what happens to the economic surplus (Dasgupta 1985, p. 15). The other is the power to manipulate demand in a way that promotes one innovation while stifling another. Sraffa (1926) first recognised the power of marketing, which was subsequently developed by many economists, but notably Robinson (1933), Sylos-Labini (1962) and Galbraith (1958). ${ }^{4}$

The perspectives will be examined with two objectives in mind. The first is to appreciate the limits to innovation. These limits are specified by each particular perspective with each identifying the role of business planning and public policy in overcoming these limitations. The second is to identify common themes that could form the basis of a general framework of technological innovation. This framework has a Galbraithian base as it encompasses the uncertainty principle by institutions that handle the tension between planning strategies and unconstrained environments.

The innovation process is the generation of ideas and their implementation (often called 'commercialisation' when it occurs in a private sector business environment). Jolly (1997) calls this the process of getting ideas from the 'mind to the market', and he identifies in his research five interconnected stages in the process:

- Imagining - which generates technological solutions with problemsolving skills.

- Incubating - which develops concrete applications of the technological solutions.

- Demonstrating - which tests designs and validates outcomes of technological applications.

- Promoting - which positions the demonstrated technology into appropriate market(s).

- Sustaining - which improves functionality through incremental improvements. 
The various perspectives examined below emphasise different aspects of this five-stage innovation process, and the articulation of these perspectives will be in the context of the aspects of this process which each perspective concentrates its analysis.

Seven factors make up the criteria that are applied to appreciating the role of technological innovation and its influence on the society. Each perspective is examined to see which of these factors are specified and the role that they play in the innovation process as identified by Jolly (1997). The seven factors are:

1. Source of creativity in the imagining and incubating stages;

2. Bridging the invention-innovation gap to fund and technically support the demonstrating stage;

3. Promoting the technological applications for the diffusion of innovation;

4. Role of investment and effective demand in sustaining the innovation;

5. Contextual analysis related to firm size, regional location and industrial sector;

6. Trend and cycle patterns in the laws of motion for innovation;

7. Role of government in relation to the whole technological innovation process.

\section{PRO-MARKET PERSPECTIVES}

The agency that is central to the determination of technological innovation in neoclassical economics is 'The Market'. The firm is seen as reflecting the will of the market determined through contracts of exchange, with economic agents carrying out the dictates of the market. This agency perspective is consistent with market dominance developed by economics writers in the marginalist revolution post-1870. The Walrasian general equilibrium system describes a pure exchange economy without any consideration of production. The Marshallian partial equilibrium system attempts to integrate the theory of exchange with a production system anchored in industries that are made up of a set of heterogeneous firms (Best 1992, p. 4). Industries, not firms, are central to the determination of price and quantity through the interplay of supply and demand forces in each industry setting. Any advantage gained by one firm quickly spills over to other firms in the same industry evening out the industry's firms. Bloch and Finch argue that:

Despite irreducible heterogeneity among firms in often localised and clustered industries, the tendencies that prevent one firm from getting a lead and benefiting from faster accumulation or internal economies mean that the famous representative firm of Marshall's principles has some (logical) credence or tractability. (2004,p.5) 
The source of creativity is in the market itself, or in Marshall's terms it is 'in the air'. The knowledge inherent in innovation 'leaks out' quickly and easily through communication of customers, suppliers, rivals, educational institutions, etc.. This spillover occurs around localised districts (or clusters) in Marshall's world, but this can extend to electronic networks and globalised strategic alliances (including franchising and licensing). Innovation gradually builds upon previous knowledge and its diffusion is very quick and effective. Incentives through early technical knowledge are brief, with first-mover advantage the longer-term objective. Source of innovation is, thus, exogenous to operation of the market. That is why Nelson and Winter (1982) use random draws for innovation knowledge in their simulation model of enterprise development.

Bridging the invention-innovation gap is problematic from the neoclassical perspective, because the market works on the basis of information spreading quickly (if not instantaneously) to enable the innovation knowledge to diffuse. The process of bridging the gap is not of significance per se; only when market forces are prevented from diffusing the information is there a legitimate reason for passive public policies to dissuade such prevention. Promotion through advertising and other marketing techniques is important in differentiated markets, but only as a temporary competitive advantage to be whittled away by competitors marketing strategies. The criterion of investment in sustaining innovation is essential but not a driver of innovation, only a response to the market situation. The market is the power.

The contextual criterion in neoclassical economics is crucial in the Marshallian strand that has influenced generations of industrial organisation researchers. This is the biological analogy of firms as trees, where they '... gradually lose vitality; and one after another they give place to others, which ... have on their side the vigour of youth' (Marshall, 1920, p. 316). This implies that firms do grow, but then decay, so that no firm becomes too large over a long time so as to dominate the industry. The role of regional clustering and industrial location is linked to this biological need to group together in order to be sustainable. This sustainability is only in a quasi-equilibrium state such that there is '... dynamic balance between progressive and declining firms, with today's progressives inevitably becoming tomorrow's decliners' (Bloch and Finch 2004, p. 5). This analogy also provides a trend around an equilibrium stationary state position for the 'forest of firms' as a whole, with the representative firm providing some medium firm in this industry, with only exogenous shocks like radical disruptive technologies disturbing the 'biological' balance. Trend is the statical balance with heterogeneity being competed away quickly. Any major disturbances causing cycles are exogenous shocks to the system.

The role that government plays in the innovation process in neoclassical 
economics is passive and reactive. Any exogenous shocks and distortions that threaten the biological balance need to be addressed by policies that ensure the stability of private investment decisions. This stability derives from the state's attention in establishing the 'benchmark' competitive conditions that lead to a stable market-based economy (for example legislation on: anti-trust, consumer protection, anti-discrimination, intellectual property rights). These benchmark conditions allow the price signals to arise, and for them to be the basis upon which private entrepreneurs respond. This benchmarking begins from the premise that human agency responds to flexible market signals by tending towards a known (or at least knowable) equilibrium stable condition. The dynamic aspect of this neoclassical position is the exogenous element of technological innovation. It is such technology that is assumed will come forward under correct market signals. This innovation is seen as being appropriated via investment, but with no specific theory on how it happens. Empirical evidence on technical change comes forth as only a 'residual' to all the basic internal static economic factors that are explicitly price responsive (see Denison 1962).

Critical response to this neoclassical view of innovation centres on the dilemma of limits to innovation. On the one hand there are no limits because price signals will always respond to shortages in the market, stimulating technological innovations that will overcome such problems. On the other hand, the fact that technological innovation is merely a residual in the economic model makes any efforts to understand, model and act on any specific conditions impossible. This limits innovation to purely the outcome of the 'invisible hand'. The uncertainty principle inherent in this perspective cannot be addressed except in some fundamental commitment to the market faith, the signals it creates and the quick responses elicited.

The underlying critical response to this market faith is that technology itself, within the context of volatile market signals creates conditions for uncertainty in expectations about the future that lead to cumulative shortrun instability and cumulative long-run systemic change. The work by Minsky (1982) on financial instability and by Crotty (1992) on growth-safety trade off in capital goods investment, show the cumulative volatility arising from market signals to investment (both financial and physical). Recent work on technology embodied in investment has shown the rise of severe cyclical activity whenever new technological systems predominate. ${ }^{5}$ When technology becomes embedded, then past technology decisions shape future investment decisions and myopic selection pressures operate. Such pressures work against the automatic price response mechanism that would in theory induce new appropriate technology; for example, replacement technology for the petrol-driven automobile (Rip and Kemp, 1998, pp. 372-9). 
A pro-market variation to the neoclassical view comes from the neo-Austrians who see the agency that is central to the determination of technological innovation as 'The Entrepreneur'. The entrepreneur is seen as alert to opportunities for taking advantage of discrepancies and gaps in the market system. ${ }^{6}$ In this sense, the neo-Austrian version of the entrepreneur is an arbitrager; a persona embodying foresight, knowledge and willingness to act in situations of widespread ignorance of the disequilibria that exist in the market that comes out of the criticism that the neoclassical position lacks any subjective human element to agency (Canterbery 1995, p. 262). Exploiting opportunities in a rational planning manner adds to the value of the final product by the techniques that are 'put to use'. The more capital-intensive the process of production, the more capital goods are put to use through increasingly complex techniques and the higher market price that the product can command. Value is thus added by the 'degree of roundaboutness', leading to capital deepening in the economy (Kirzner 1973). The appropriation of monopoly power in the market is evidence of creative and successful entrepreneurship. Such monopoly power is not seen as permanent by neoAustrians unless such power is underwritten, subsidised and otherwise supported by governments and their regulatory agencies.

Promoting the innovation provides the competitive advantage, similar to neoclassical economics. As an arbitrager, the neo-Austrian entrepreneur identifies and reveals the ends latently demanded in the economy. Marketing is merely the process of informing market participants of the opportunities created by entrepreneurs. Any monopoly power that is established from marketing will be slowly undermined in the marketplace rather than the quick response assumed by the neoclassical version of this promotion story.

The neo-Austrians have a strong accumulation link from innovation to investment, and it is driven by the entrepreneur's need to produce the final marketable product. Effective demand is latent and always waiting for the entrepreneur to exploit. The investment process continually alters the structure of capital, where this capital is the only factor of production and embodies anything that the entrepreneur invests in (human, physical, natural or social) to produce the final product (Kirzner 1976). Contextual relevance to this entrepreneurial process centres on Schumpeter (1934) and the role of small innovative firms developing the creative niche in capitalism that is the bulwark of technological innovation, which reflects the capitalism of the nineteenth century. The laws of motion are governed by the actions of the entrepreneur, with cycles being the subjective reflections as well as signals of these actions. Surveillance of market-created rules under the principles of private property is the one role of government in the process of innovation and economic development. Laissez-faire is rationally necessary for 
entrepreneurship to flourish, with judicial outcomes protecting private property rights being the centrepiece of public policy.

For the neo-Austrians, innovation is only limited endogenously by the imagination and creativity of entrepreneurs and exogenously by the heavy hand of government restraining opportunities through regulation. Both limitations are subjectively bounded by the operation of individual creativity and by the negative reaction of entrepreneurs to regulation. There is much research on the most effective ways of unlocking the creative potential for business (e.g. Amabile 1997) but this does not provide a model of creativity that can be used to understand economic development of the innovation process, nor an appropriate comparator of different innovation systems. There is also no guidance for public policy for innovation, since subjective individualism drives innovation. ${ }^{7}$ Uncertainty underlies finding opportunities and delivering outcomes. This is the crucial dynamic element that drives the entrepreneur, but it is not analysed in a way that would facilitate the better handling of uncertainty for potential entrepreneurs. Thus, it is not clear whether entrepreneurial actions will deliver the desired outcomes. Examples of actions by entrepreneurs in the corporate collapses of the early 2000s ('tech wreak', Enron, WorldCom, Martha Stewart) indicate that optimum social outcomes may not always result (see Clarke et al. 2003).

The pro-market perspectives outlined above view market signals as the dynamic of capitalism. Whereas the neoclassical mainstream adopts an objective commitment to market processes; the neo-Austrians base their market faith on a subjective nature of human action. Both have an approach to innovation that harks back to the individual entrepreneurial economy of the nineteenth century. Power of the entrepreneur is dominant in these perspectives, either implicitly (neoclassical) or explicitly (neo-Austrian), while the effects this power has on civil society in monopoly capitalism is ignored, especially in terms of the lack of both transparency and ethical responsibility. At the beginning of the twenty-first century, this approach can be a rationalisation for capitalist excesses in a globalised economy where the rule of national law is becoming much more tenuous.

Although the classic entrepreneur still exists, empirical evidence suggests '...that only a minority of new companies survive, and that these are often not particularly innovative' (Sundbo 1998, p. 157). ${ }^{8}$ The innovation process has become institutionalised since Thomas Edison introduced the research and development department into his innovation of a longer-lasting light globe. Technological innovation has to a large extent become organised, 'managed' and taught in MBA programmes (see note 1). This opens the door for Galbraith to provide an institutional approach to technological innovation. 


\section{GALBRAITH AND THE INSTITUTIONAL PERSPECTIVE}

The rise of big business in the twentieth century moved the dynamic of agency away from the individual entrepreneur. NIS provides a way of understanding this dynamic on technological innovation by recognising the laws of motion within the large corporations, but incorporating into this trajectory a strong agency story. The agency that is central to the determination of technological innovation in NIS is 'The Technostructure'. The technostructure is seen as the decision-making basis of the large corporations that forms 'the planning system' of advanced capitalist economies and which guides economic development. This agency group embraces specialised knowledge, talent and experience in specific technology-based areas where the market system (and its small enterprises) is symbiotically subservient to the decisions of large corporations, while governments need to acquiesce to the planning system's power and influence. NIS developed this large firm dominance approach from Schumpeter (1942), where the small firm entrepreneur of Schumpeter (1934) gives way to a managerial class who are concerned to protect and support increasingly sophisticated technology in a planned approach. Power lies with the technostructure inside large corporations who serve partly the capitalistowners through share price and dividend sustainability, with increasingly generous serving to themselves via remuneration packages and perquisites of office (Stilwell 2002, p. 232).

NIS forms the basis of a critical institutional school response to the power of big business. Galbraith in NIS reaches back to the seminal early works of Thorstein Veblen and linking with contemporaries like Clarence Ayres. ${ }^{9}$ Although clearly having an institutional focus, NIS has a sophisticated methodological enquiry that is evolutionary, emphasising the role of major institutions in shaping economic and social development. In the context of technological innovation, it is the technostructure that is the major agent of change that results in corporate dominance, environmental stress, deep military-industrial complex, financial instability, as well as globalised market and cultural penetration. All this can be described as an interlocking complex set of innovation systems operating at global, national and sub-national (or regional) levels. ${ }^{10}$

Sources of creativity in technological innovation are a two-edged sword from this perspective. The technology imperative demands from the technostructure two actions. First, the technostructure needs to stifle competing radical innovations from individual entrepreneurs of the classic neo-Austrian variety (see Lessig 2004). Second, the technostructure needs to commit funds for internal research and development (R\&D) in the incremental innovations of existing corporate technologies (see Chiesa 2001). These two 
actions tend to limit innovation to what a bureaucracy can produce in a planned system, underlying a certain hard-core level of technological determinism. Schumpeter (1942) expressed concern that the dynamism of innovative entrepreneurship will be eroded by the technostructure sheltering their large corporations from 'the gales of creative destruction'.

The large corporation bridges internally the investment-innovation gap by first funding R\&D and then commercialising the projects that are deemed by the technostructure as having the potential for success (see Jolly 1997). This leads to circular and cumulative causation, ${ }^{11}$ where the dynamic forces of innovation support certain forms of innovation to the detriment of other innovations. Self-perpetuation through monopoly control in the physical dimensions of innovation leads to a virtuous cycle of incremental innovation by large corporations. This is perpetuated in MBA courses that develop models for managing technological innovation (e.g. Ettlie 2000). On the other hand, there is also the vicious cycle of disadvantage, prejudice and legal constraints that prevent the investment-innovation gap from being met by funds and other support. Support to traverse this gap does not easily trickle down to small innovative entrepreneurs (see Kingston 1984; Lessig 2004).

Galbraith (1958) develops the concept of producer sovereignty to replace consumer sovereignty, the neoclassical term to express consumer choice in the market. Under a planning system, the large corporation needs to reduce fundamental uncertainty of new innovations by channelling huge resources into market research (or 'wants-creation' process) and developing a marketing plan that creates product acceptance and brand loyalty. This is the promotion aspect of innovation from the institutional perspective. The acceptance of a strong consumerist ethos is a necessary pre-condition for producer sovereignty to work in the aggregate. There will always be specific examples of failures in marketing, but its overall success is evident from the continual development of consumerism both in advanced economies and now spreading through to strongly developing economies like China. ${ }^{12}$ Galbraith often quips: 'It is the exception that proves the rule.'

Another cumulative causation aspect emerges with the role of investment and effective demand in innovation. Heilbroner (1961, p. 263) identifies that capitalism's investment rests on the shoulders of technological progress alone, which carries with it an inherent instability:

The great inventive contributions of mankind had always come in sudden bursts: an era of industrial revolution; an era of railroadization; an era of electrification; another of automotive building [and yet another era of information technology building - JC]. Each cluster of inventions had resulted in a spurt of investment, but when each had run its course, the hectic activity of building was succeeded by a period of quiescence. 
This instability of innovation has been dubbed the 'clust-bun' effect; clustering of inventions leads to bunching of investment to intensify existing business cycle activity. The virtuous 'clust-bun' effect requires effective demand stimulus through widespread diffusion of the clustering phenomenon that can only be achieved through the availability of profits for investment determined by the technostructure, often politically and financially supported by public sector funding..$^{13}$

Impediments to the 'clust-bun' effect reside in the institutional frameworks of nations (national innovation systems), particularly the ones with stilldominant mature industries utilising older technologies (Freeman and Perez, 1988, pp. 58-65). Increased uncertainty arising from large investment in the new technology systems also adds an impediment through increased macroeconomic volatility, which Toivanen et al. (1999) empirically identify as slowing down the diffusion process. $\mathrm{R} \& \mathrm{D}$ (and technology transfer thereof) provides large corporations with the potential means to overcome these impediments and set up their own national innovation systems, with profits determining the volume of R\&D that firms can undertake. Thus, the size of firms will reflect how successful the technostructure is in overcoming impediments in their own terms. The greater this success, the larger and stronger monopoly control will be exerted by large corporations. Then, there would be less space for small enterprises to prosper, unless they are symbiotically linked to the large corporations (e.g. component makers for automobiles and computers). This provides a clear and consistent adaptation and modification to Galbraith's technostructure concept in the light of capitalist developments in technological innovation since publication of NIS.

The cumulative causation process has a regional inequality dimension to it. So, firms that cluster in one industrial location, strongly supported by one or a few large corporations, create strong regional innovation systems. Meanwhile, peripheral industrial regions without large and expanding corporations will tend to lose their entrepreneurial people to strong cluster regions. This is what Myrdal (1957, p.27) calls the 'backwash effects' in regional economies, from an economic development perspective.

In the classic evolutionary proposition by Schumpeter (1939) the investment function responds to waves of optimism and pessimism to create clusters of inventions, which then are diffused through the bunching of investment: the 'clust-bun' effect. This leads to investment cycle patterns and the development of a trigger mechanism to significantly increase the rate of investment in endogenous (incremental) innovation on the basis of a specific exogenous basic (or radical) innovation already created by the established large corporation. At the bottom of the investment cycle a trigger to initiate a 'virtuous cycle' effect occurs with investment rising to diffuse basic innovation. This increases the amplitude of the expansion phase of the 
investment cycle, raising innovation intensity and shifting the trend path of economic growth upward. ${ }^{14}$ An opposing 'vicious cycle' effect works to reduce innovation intensity, thus sending the investment cycle into a significant contractionary phase.

From NIS, the role of government in technological innovation is to support the technostructure through the educational and scientific estate made up of teachers and researchers in schools, universities and non-profit research centres. Their intellectual work and social organisation 'are woven into the work of big corporations, which provide research funds, endowed chairs, and lucrative consultancies in exchange for these valuable new technologies and techniques' (Parker 2005, pp. 440-1). This estate generally does not challenge the order of the corporate planning system and is bound to it by mutual love of what Galbraith called 'technological virtuosity' and the social prestige it engenders.

Galbraith's institutional perspective is strongly based on a public sector interventionist position. The political power imbalance clearly needs to be addressed by reformist public policies that aim to provide more balanced development by supporting regions, industries, unions, communities and independent innovators that do not have the support of the technostructure. The innovation policies need to be active and positive in the direction of encouraging variety, fostering experimental behaviour, supporting new developments, focusing on system building, enhancing diffusion, promoting learning organisations and their skills training, as well as assisting to influence expectations (through broad-based grants, tax concessions, mentoring, and supporting small business services)..$^{15}$

The major contribution from this perspective is the holistic approach to analysis and policy, recognising interdependencies with dynamic evolutionary forces. This requires complex economic dynamics that can identify systemic (rather than market) failure and interventionist policies to overcome such failures. Many examples of success in this innovation approach can be noted: war-based economy, reconstruction from major devastation (e.g. the Marshall Plan), national sports-based academies, regional clustering around universities and technology parks.

Four major criticisms of the institutional perspective can be identified: (1) Given the large monopoly planning power of the technostructure it is unclear how a government can escape from their acquiescent policy framework into the more balanced approach advocated by these economists. In fact, this planning power will ensure that any 'balanced' attempts will be skewed to favour the large corporations through special interest lobbying and pleas by neoclassical economists of the erroneousness of profligate state spending on picking 'so-called' winners. (2) The vast majority of job creating companies are fast-growing start-ups (or gazelles), independent of the 
technostructure (Birch et al. 1999), especially with the downsizing of large corporations through the 1990s. (3) Affluent electoral majorities in advanced capitalist economies are enjoying the fruits of a consumerist society and no longer look to government for social betterment of society in a balanced way, but instead demand security to protect their materialist gains from what Galbraith calls 'the underclasses' that exist both inside and outside national borders (see Lasch 1995). (4) Technological and historical determinism that underlies the advance of innovation is being undermined by the higher-order strategic planning process of professional managers, leaving the middle level technicians to work at a purely operational level (see Sundbo 1998, p. 116).

\section{GALBRAITH AND THE RESOURCE-BASED PERSPECTIVE}

The four criticisms of the Institutional perspective above can be directly addressed by the resource-based view (RBV) that centres on the strategic organisation of the innovation process. The agency that is central to the RBV is 'The Firm'. The firm from this perspective is an administrative unit that develops a 'life' of its own and is not distinguished from the actors who operate inside this organisation. Penrose (1959) is the major inspiration for this perspective that has now become the mainstream perspective in the business management discipline. ${ }^{16}$ The focus is on the firm's internal development through a dynamic capabilities framework, without explicitly establishing an innovation theory. Competitive advantage is seen not from the firm's interaction with the external market, but instead based on coordinating and combining the following core competences: distinctive assets, specific processes and critical know-how. ${ }^{17}$ All three are developed from learning-bydoing in a path-dependent way that produces increasing returns. This destroys the fiction on constant returns that neoclassical economics depends on to deliver an equilibrium position.

Galbraith is seen from this RBV perspective as supporting the technocratic role of the professional manager, separating ownership from management and developing a internal organisational structure based around strategic planning (Sundbo 1998, p. 141). Galbraith uses this internal corporate structure to focus on the politico-economic role of large corporations on the external society, while Penrose focuses on how corporations organise their internal resources. In the process, the RBV is consistent with an acquiescent political system, a consumerist society and strategic (rather determinist) core. Penrose also provides a clear growth process for independent start-ups to becoming large corporations, something Galbraith does not entertain. 
The source of creativity in the RBV perspective comes from the ability of the firm to gather together distinctive core competences. This starts with management of the imagining stage to generate ideas (see Amabile 1997), right through to the sustaining stage of the idea over the long term (see Jolly 1997). What ultimately limits innovation is the capacity of the firm's management to implement and learn from the five-stage innovation process. Organisations need to develop behavioural patterns and habits called 'routines', in order to make decisions on future actions. These routines are based on a repertoire of skills that evolve over the life-cycle of the organisation as learning and selection occur.

Bridging the invention-innovation gap is an integral part of the management's ability to work through the first three stages of the innovation process. Growth of the firm comes from the ability to free up internal resources so as to create managerial services for new diversified opportunities. This is more important than engaging in zero-sum games with competitors like price discounting, cost-cutting, downsizing and developing barriers to entry; since competing firms will retaliate with similar actions that will rebound on the initial instigator.

The promotion of innovation through marketing is seen as just another of the core competences that needs to be effectively managed. In fact, it is argued that market position in the context of rapid innovation is extremely fragile and difficult even to identify. 'Moreover, the link between market share and innovation has long been broken, if it ever existed' (Teece et al. 1997, p. 319). Considering the role of investment in the innovation process, it is surprising that this aspect is not discussed in any great detail by this perspective. Consistent with RBV, investment is seen as a capital budgeting process that shapes both the introduction of new capital stock into the firm and also the decommissioning of old capital stock. The management process for capital budgeting involves traditional net present value calculations, together with developing a portfolio of investment opportunities and calculating the option value of participating in new technology - contingent on competitor behaviour (Ettlie 2000, p. 192).

Whereas the previous perspectives clearly specified the firm size of innovation champions, RBV follows Penrose in identifying the precise circumstances and actions of the firms that determines innovation champions. Scherer warned in 1980 (p. 418) that ' $[\mathrm{t}] \mathrm{he}$ search for a firm size uniquely and unambiguously optimal for invention and innovation is misguided'. There is strong theory and evidence to support both small and large firm innovation propensity. In fact, medium-sized firms tend to be the most disadvantaged, since they lack the dynamism of small entrepreneurship and the wherewithal of large firms to conduct R\&D. However, '[un]equivocal evidence is found that [market] concentration exerts a negative influence on the number of 
innovations being made in an industry' (Acs and Audretsch 1991, p. 14). This means that innovations can emerge as much from small firms as from large firms, thus industrial and regulatory policies cannot be based on simple rules about firm size but more related to market power through high concentration in particular industries. In general, the role of government is active supportive (e.g. removing monopoly rents), but not in the positive reformist approach of the institutional perspective.

Collaborations between firms are a crucial element of the learning process in RBV and recent studies have identified the technological and marketing innovative benefits that emerge (see Coombs et al., 1996). Networking from collaborations by (and with) small and large firms has significant implications for regional clusters (or industrial milieux) both in geographic and cyberspace. In this way, innovation diffuses over space through the process of knowledge spillovers that operate at different rates of diffusion across technology gaps. The laws of motion that this perspective concentrates on relates to the evolution of technological innovation. The initial approach was the life cycle (or S-curve) from birth to decay (or transition). Since then more sophisticated approaches have emerged for large firms, particularly punctuated equilibrium and jolt theory; whereas small firms still tend to resemble the neoclassical 'forest of firms' (Ettlie 2000, pp. 76-82).

The constructive elements of this perspective come from the hard-nosed empirical research underpinning the concepts outlined, using specific measures of innovation and coming up with practical strategies for the management of innovation. Planning, thus, is seen as a cooperative process in tune with market reality - linking markets with the planning system. On the negative side, RBV 'is still too undeveloped to function as a unified basic theory'. (Sundbo 1998, pp. 157-8), and despite its empirical disposition, many measures used are acknowledged as unsatisfactory, especially in trying to identify innovations themselves and the core competences that create them (Acs and Audretsch 1991). Core competences can also be limiting when they become core rigidities and then firms underestimate or neglect emerging core competences arising in the economy. This leads to ignoring market demand, leading to the problem of effective demand and its limitation on innovation. From this emerges the most critical factor, essential in Galbraithian institutionalism, that there is the lack of power as a crucial element in the innovation process, despite the occasional reference to market concentration strength as a negative influence on innovation. One aspect that could reflect a fresh angle on power is the neglected notion of an 'innovation mechanism' by Downie (1958), 'whereby laggard firms have a greater incentive (the need to survive) to undertake risky R\&D work that might provide them with ways to re-establish their competitive position' (Bloch and Finch 2004, p. 12). 


\section{GALBRAITH AND THE POST-KEYNESIAN PERSPECTIVE}

A macroeconomic perspective on the technological innovation process is lacking in all the previous perspectives. Their emphasis is on the industrial organisation of innovation. Galbraith's own Keynesian predilections gave him a strong effective demand macroeconomic view, but this has never been wedded to his technostructure and the political economy of technological innovation. A small group of economists working in the Kalecki-Steindl tradition have made a significant contribution to the macroeconomic demandoriented aspects of technological innovation that helps to appreciate the economic development and volatility of modern neo-liberal capitalism. On the scale of technological determinism, this contribution is further to the soft end than the institutional or RBV perspectives because of its emphasis on the power of capitalists' own behavioural decision-making.

The agency that is central to the determination of technological innovation is 'The Capitalist'. The capitalist links innovation to investment decisionmaking so that the elements of effective demand and cyclical volatility at the broad base are related to the cumulative processes in all forms of innovation at the firm/industry level. This perspective derives from Keynes (1936) and his clear view that investment (in capital stock) is the essential, but 'undependable' drive wheel for the economy. Co-progenitor of the postKeynesian perspective, Michał Kalecki, identifies the historically determined profit levels as generating the ability to invest in capital goods and in innovation knowledge enhancement. Profits (or surpluses in non-profit organisations and public authorities) not only provide the wherewithal to invest, but also through their extension of the capital funds owned by the organisation ('entrepreneurial capital'), it also allows for access to loans and share issues ('rentier capital'), which can further extend capital and knowledge-based investment (Kalecki 1991, p. 279).

Capital accumulation is embedded in the endogenous (or induced) innovation generated from within the organisations (via R\&D expenditure, and knowledge spillovers). Such innovation is of secondary importance from the scientific standpoint, coming as it does from: (1) slight adaptations on previous capital equipment; (2) cosmetic improvement in old products; and (3) extension of previous raw material sources. Kalecki calls the 'innovation effect' a 'development factor' which creates the following dynamic process:

innovations prevent the system from settling to a static position and engender a long-run upward trend. The accumulation of capital, which results from the fact that long-run investment is above the depreciation level, in turn increases the scope of the influence of the development factors and thus contributes to the maintenance of the long-run trend. (1991, p. 327) 
Kalecki, then, sees 'exogenous' innovation as representing the intensity of innovation with given capital investment levels. This means that any change in the intensity of the innovation effect originates in the scientific invention or basic business opportunity identified as the source of the innovation. So that a:

reduction in the intensity of innovations ... will also initially cause a disturbance in the cyclical fluctuation and, by means of a slump more pronounced than the boom, will make for a lower long-run level of investment. (Kalecki 1991, p. 328)

This would lower the long-run trend, where an increase in innovation intensity would raise the long-run trend in economic growth.

$\mathrm{R} \& \mathrm{D}$ amounts in aggregate to a large body of investigation going on continuously (at different rates of intensity). This large R\&D spending and related innovation effects are bound to lead to some major new 'discovery' or 'invention' which is related to the total aggregate $\mathrm{R} \& \mathrm{D}$, rather than any one particular R\&D project. This discovery is linked to possible small developments in various laboratories and informal networks between firms and industries, eventually coming to fruition in some way divorced of any specific competitive behaviour. New technological paradigms come out of such aggregate developments and are the basis of structural change to a new long wave of boom and prosperity (Freeman and Perez 1988, pp. 47-58). Changes in technological systems and paradigms arise only after all the minor improvements (endogenous innovation) are squeezed out of the old systems and paradigms by 'monopoly capital' entrepreneurs who want to protect existing capital stock and delay the new paradigm taking over. There is also 'log jam' in endogenous innovations based on the new paradigm which compounds the latter's slow initial adoption. This occurs when established powerful capitalists, with much old capital stock, cannot justify the entire shake-up of industries, since not enough interrelated clusters have been formed.

As the Galbraithian institutional framework slowly adapts to the new technological system, capitalists' reactions against uncertainty of profits come from competitive pressures and growing inefficiencies of old capital stock. This induces adaptation (by industries) and imitation (within industries) to technological trajectories that are totally new, establishing the new investment upturn. It is creating a new investment boom and at the same time reestablishing the conditions for a new phase of steady development. A paradigm shift occurs when the new adapted technological systems pervade the whole economy.

This analysis links together the two types of innovations described by Baran and Sweezy (1966), namely 'normal' (or endogenous) and 'epoch-making' (or exogenous). A period of secular decline in economic development can now be associated with the limitations of scale production in oligopolistic 
competition, as the old technology systems are running out of possible new adaptations. Diffusion of the old systems through endogenous innovation slows down and imitators become considerably fewer. The large powerful corporations attempt to protect existing capital values and ignore the new technological systems being developed on the fringe of the corporate world. This tends to exacerbate the mismatch between new technologies and powerful institutional framework based around monopoly capital. It was Steindl, back in 1952, who recognised this secular decline as the incentive to reduce surplus capacity and invest in established monopoly capital sectors. In his 1976 introduction to the 1952 book reprint, Steindl stated that he was 'ready to admit a possibility which I denied in my book: that it might be the result of exhaustion of a long technological wave' (1976, p. xv).

Courvisanos (1996, pp. 225-30) outlines in detail three public policies: (1) demand management to regularise investment cycles at the macroeconomic level; (2) encouraging innovation into new technological systems at the microeconomic level; (3) 'socialisation of investment' through perspective planning at the mesoeconomic level as countervailing power to the planning system of monopoly capital. The post-Keynesian perspective provides a more short-term demand-oriented response to innovation policies, but it is the lack of a broader institutional aspect to innovation that limits the post-Keynesian position. Ignorance of the roles of competition (neo-Austrian) and collaboration (resource-based) in the innovation process opens up the criticism that despite the appropriate demand conditions and public support, without these two dynamic elements of firm innovation, the innovation process could be heavily compromised as it was during the command economy period of Eastern European economies (see Marangos, 2004).

\section{A GALBRAITHIAN HETERODOX SYNTHESIS}

Galbraith and NIS provide the impetus for a heterodox analytical framework for technological innovation. ${ }^{18}$ Galbraith's institutional base provides an effective PE critical response to the pro-market perspectives on technological innovation, but at the same time giving a level of technological determinism to the innovation process that raises concerns for its viability as a complete framework. The work of resource-based strategists at the internal organisation level and post-Keynesian economists at the macro policy level has the potential to develop a more comprehensive and less determinist framework. The intellectual support of Galbraith and his NIS thesis in the RBV and postKeynesian perspectives as they relate to innovation can be incorporated into the Galbraithian institutional framework. The following themes form the basis of this heterodox synthesis: 
- Endogeneity: Innovation arises from within the system with recursive effects and increasing returns, and is not some exogenous or independent force. Galbraith recognises that through the technostructure innovation is generated and then efforts are applied to manage the process.

- Uncertainty: Need to 'manage' uncertainty is crucial for the innovation process. The pro-market perspectives have mechanisms that assume the change agents can handle uncertainty automatically. The Galbraithian element in all the three other perspectives develop more open-ended approaches to uncertainty, identifying various political, social and corporate elements that 'manage' uncertainty through strategy, power and influence.

- Evolutionary: Innovation is a process of change that evolves from some embryonic revolutionary idea to different types of innovation: infant (radical), growth (incremental), maturity (stagnant) and then either declines or transforms (diversifies). Dynamic mechanisms are developed by all the three critical market perspectives to address implications of evolution.

- Individualism: A person (or team) drives the innovation process through entrepreneurship. The process can be based on competitive and/or collaborative arrangements in the commercialisation of the innovation. Galbraith identifies the technostructure and the collective organised teams (e.g. R\&D departments) within large organisations that drive innovation, but the RBV also recognises employees as champions (or intrapreneurs) who are catalysts.

- Strategic planning: Managing and strategising innovation in a planned approach is a strong antidote to the idea that it just happens by the power of individualism. This shifts the innovation process from psychological (individual) and technocratic (scientific) to organisational and marketing; a process begun by Galbraith.

- Investment: Where the pro-market perspectives see investment only as some automatic response to market signals. Empirical evidence on the basis of sound Keynesian principles shows that investment decisionmaking is needed to deliver technological innovation in a mass capitalist economy. This requires basic post-Keynesian foundations related to profits, debt and productive capacity (see Courvisanos 1996).

- Supportive state policy: The need for public policy to support the innovation process is recognised explicitly (institutional and postKeynesian) and implicitly (RBV and neo-Austrian). The differences relate to questions of passive versus active intervention and the underlying reasons that the state is 'induced' to provide this support. Neoclassical, neo-Austrian, and RBV (to a less extent) see public policy 
as needing to be passive while ignoring the PE reasons for its support. The institutional response is strong in terms of PE and the need for reformist active intervention, despite the fundamental contradiction identified earlier. Post-Keynesians have strong active support but without the political-institutional depth of Galbraith. Some studies have combined institutional and post-Keynesian elements into a public policy framework to address these political economy concerns (see Freeman and Perz 1988; Lima 2000; Courvisanos and Verspagen 2004).

\section{CONCLUSION}

A Galbraithian heterodox synthesis should provide a strong generic framework to understand and appreciate the capitalist forces that underlie technological innovation and its commercialisation process. A thumbnail sketch of such a framework has been provided in this chapter. A deeper policy analysis that emerges from this synthesis could form the basis of a substantial development in strategic planning and public policy analysis. This could provide improved ability to cope with the uncertainty that arises from the dynamics of technological innovation and accompanying capital investment. At the same time this generic framework can be used to take advantage of the susceptibility of other firms in a dynamic competitive environment in order to innovate and develop competitive strengths. Finally, such a synthesis enables some rigorous guidelines to be established for further empirical research on the political economy of technological innovation.

\section{ACKNOWLEDGEMENT}

I acknowledge my appreciation of the advice and suggestions made by Stefan Kesting and Geoff Harcourt.

\section{NOTES}

1. See books like Jolly (1997), Ettlie (2000), and Betz (2003). For selected significant articles in this genre, see Tushman and Anderson (2004).

2. Rosenberg (1982) is an example of a strong historical approach to researching innovation that has important implicit PE implications. See also Landes (1969), von Hippel (1988).

3. For example, opening up of new sources of raw materials requires enormous input of new capital stock. Even the creation of a new organisational structure is technology-based if it requires significant new capital equipment to make the reorganised structure work effectively. This 'new investment' condition qualifies all the five innovation forms defined by Schumpeter (1934, p. 66) into this definition of 'technological innovation'. 
4. Kingston (1984) provides (to my knowledge) the first attempt to synthesis these two political economy dimensions to innovation. Sundbo (1998, p. 156) argues that at the end of the twentieth century it is the marketing dimension that has become the greater challenge and the driving force behind innovation.

5. Courvisanos (1996) has combined the Minsky and Crotty analyses to develop a 'susceptibility cycle' of investment at the agency behavioural level involving technological innovation. Case study patterns provide support to this concept of cumulative instability. See also Freeman and Perez (1988).

6. Neoclassical economists call such discrepancies and gaps 'disequilibria in the market'. See Kirzner (1973) for a modern-day exposition of Neo-Austrian entrepreneurship.

7. Hayek (1948) explains how little we know from an objective basis of human activity.

8. Sundbo (1998, p. 160) goes on to argue that 'the number and significance of the entrepreneurs compared with the large, complex companies have been weakened.' The global entrepreneurship monitor (GEM) of 'entrepreneurial activity' only shows new business ventures out of necessity or opportunity identification (see Reynolds et al. 2002). Although job creating in the short term, generally such ventures do not survive and do not involve technological innovation, as identified in empirical studies quoted by Sundbo (1998 p. 157).

9. Ayres (1952) has been described as a strong case of technological determinism. However, Lawson $(2004$, p. 5) notes 'on closer reading, as with Marx, the point that emerges is that some technological development may be a necessary condition for some other technological development (or indeed social development).' Thus, technological determinism should not be seen as some mechanistic operation. All technological change is contingent on how technology is 'shaped' by human agency processes as social groups manage technological, social and economic conflicts (MacKenzie and Wajcman 1985).

10. The dynamic forces of this complexity system approach to innovation are outlined in Bryant and Wells (1998). On complex economic dynamics, see Rosser (1999).

11. This concept was originally outlined by Thorstein Veblen and developed across a broad range of issues by Gunnar Myrdal (see Argyrous 1996).

12. For a recent evaluation of Galbraith's work as it applies to fundamental uncertainty, see Dunn (2001). For new psychology-based research that supports producer sovereignty and the consumerist context, see Kahneman (1999).

13. See Courvisanos and Verspagen (2004) for empirical support on the 'clust-bun' effect.

14. See Toivanen et al. (1999) for empirical support on this virtuous cycle effect.

15. Modern neo-Schumpeterian economists spell out such policies in detail (see Bryant and Wells 1998). For a neo-Schumpeterian overview from one of its leading lights, see Nelson (1987).

16. A significant contribution to this perspective by economists working in this field is Dosi et al. (2000).

17. This sidesteps entirely the planning versus market dichotomy that characterises the previous perspectives.

18. Heterodox interface has become an important part of communication amongst many nonneoclassical schools of economics; in an effort to develop dialogue, learn from alternative approaches and find common threads of analysis. For example, the inaugural conference of the International Confederation of Associations for Pluralism in Economics (ICAPE), University of Missouri, Kansas City, June 2003).

\section{REFERENCES}

Acs, Z.J. and D.B. Audretsch (1991), 'Innovation and technical change: an overview', in Z.J. Acs and D.B. Audretsch (eds), Innovation and Technological Change: An International Comparison, New York: Harvester Wheatsheaf, pp. 1-23.

Amabile, T.M. (1997), 'Motivating creativity in organizations: on doing what you love and loving what you do', California Management Review, 40 (1) (Fall), 39-57. 
Argyrous, G. (1996), 'Economic evolution and cumulative causation', in G. Argyrous and F. Stilwell (eds), Economics as a Social Science: Readings in Political Economy, Sydney: Pluto Press, pp. 112-19.

Ayres, C.W. (1952), The Industrial Economy: Its Technological Basis and Institutional Destiny, Boston, MA: Houghton Mifflin.

Baran, P. and P. Sweezy (1966), Monopoly Capital, New York: Monthly Review Press. Best, M.H. (1992), 'The firm and market: the dynamic perspectives of Schumpeter and Penrose', Social Concept, 6 (2), 3-23.

Betz, F. (2003), Managing Technological Innovation: Competitive Advantage from Change, 2nd edn, Hoboken, NJ: John Wiley \& Sons.

Birch, D., J. Gundersen, A. Haggerty and W. Parsons (1999), Corporate Demographics, Cambridge, MA: Cognetics.

Bloch, H. and J. Finch (2004), 'Penrose and Steindl: foundations for a general theory of the firm and competition', paper presented at the History of Economics Thought Society of Australia (HETSA) Annual Conference, University of Western Australia, Perth, July.

Bryant, K. and A. Wells (eds) (1998), A New Economic Paradigm? Innovation-based Evolutionary Systems, Discussions in Science and Innovation 4, Department of Industry, Science and Resources, Canberra: Commonwealth of Australia.

Canterbery, E.R. (1995), The Literate Economist, New York: HarperCollins.

Chiesa, V. (2001), R\&D Strategy and Organisation: Managing Technical Change in Dynamic Contexts, London: Imperial College Press.

Clarke, F., G. Dean and K. Oliver (2003), Corporate Collapse: Accounting, Regulatory and Ethical Failure, revised edn, Cambridge: Cambridge University Press.

Coombs, R., A. Richards, P. Saviotti and V. Walsh (1996), Technological Collaboration: the Dynamics of Cooperation in Industrial Innovation, Cheltenham, UK and Brookfield, USA: Edward Elgar.

Courvisanos, J. (1996), Investment Cycles in Capitalist Economies: A Kaleckian Behavioural Contribution, Cheltenham, UK and Brookfield, USA: Edward Elgar.

Courvisanos, J. and B. Verspagen (2004), 'Innovation and investment in capitalist economies 1870-2000: Kaleckian dynamics and evolutionary life cycles', in L.R. Wray and M. Forstater (eds), Contemporary Post Keynesian Analysis, Cheltenham, UK and Northampton, MA, USA: Edward Elgar, pp. 205-26.

Crotty, J.R. (1992), 'Neoclassical and Keynesian approaches to the theory of investment', Journal of Post Keynesian Economics, 14 (4) (Summer), 519-42.

Dasgupta, A.K. (1985), Epochs of Economic Theory, Oxford: Basil Blackwell.

Denison, E. (1962), The Sources of Economic Growth in the U.S., New York: Committee for Economic Development.

Dosi, G., R.R. Nelson and S.G. Winter (eds) (2000), The Nature and Dynamics of Organizational Capabilities, Oxford: Oxford University Press.

Downie, J. (1958), The Competitive Process, London: Duckworth.

Dunn, S.P. (2001), 'Galbraith, uncertainty and the modern corporation', in Keaney (ed.), Economist With a Public Purpose: Essays in Honour of John Kenneth Galbraith, London: Routledge, pp. 157-82.

Ettlie, J.E. (2000), Managing Technological Innovation, New York: John Wiley \& Sons.

Freeman, C. and C. Perez (1988), 'Structural crises of adjustment, business cycles and investment behaviour', in G. Dosi, C. Freeman, R. Nelson, G. Silverberg and L. Soete (eds), Technical Change and Economic Theory, London: Pinter, pp. 38-66.

Galbraith, J.K. (1958), The Affluent Society, Boston, MA: Houghton Mifflin. 
Galbraith, J.K. (1967), The New Industrial State, Boston, MA: Houghton Mifflin.

Glaeser, E., H. Kallal, J. Scheinkman and A. Shleifer (2001), 'Growth of cities', Journal of Political Economy, 100, 1126-52.

Hayek, F.A. (1948), Individualism and Economic Order, Chicago: University of Chicago Press.

Heilbroner, R.L. (1961), The Wordly Philosophers, revised edn, New York: Simon \& Schuster.

Jolly, V.K. (1997), Commercializing New Technologies: Getting from Mind to Market, Boston: Harvard Business School Press.

Kahneman, D. (1999), 'Objective happiness', in D. Kahneman, E. Diener and N. Schwarz (eds), Well-Being: Foundations of Hedonic Psychology, New York: Russell Sage Foundation Press, pp. 3-27.

Kalecki, M. (1991), Theory of Economic Dynamics, in J. Osiatyński, J. (ed.), Collected Works of Michat Kalecki, Volume II: Capitalism - Economic Dynamics, originally published 1954 by Allen \& Unwin, London, Oxford: Clarendon Press, pp. 203-348.

Keynes, J.M. (1936), The General Theory of Employment, Interest and Money, London: Macmillan.

Kingston, W. (1984), Political Economy of Innovation, The Hague: Martinus Nijhoff.

Kirzner, I.M. (1973), Competition and Entrepreneurship, Chicago: University of Chicago Press.

Kirzner, I.M. (1976), 'The theory of capital', in E.G. Dolan (ed.), The Foundations of Modern Austrian Economics, Kansas City: Sheed \& Ward.

Lallier, A.G. (1989), The Economics of Marx's Grundrisse: An Annotated Summary, London: Macmillan.

Landes, D. (1969), The Unbounded Prometheus, Cambridge: Cambridge University Press.

Lasch, C. (1995), The Revolt of the Elites and the Betrayal of Democracy, New York: W.W. Norton.

Lawson, C. (2004), 'Technology, technological determinism and the transformational model of technical activity', paper presented at Theorising Ontology, Annual Conference of the International Association for Critical Realism, Girton College, Cambridge, 17-19 August.

Lessig, L. (2004), Free Culture: How Big Media Uses Technology and the Law to Lock Down Culture and Control Creativity, New York: Penguin.

Lima, G.T. (2000), 'Market concentration and technological innovation in a dynamic model of growth and distribution', Banca Nazionale del Lavoro Quarterly Review (215) (December), pp. 447-75.

MacKenzie, D. and J. Wajcman (eds) (1985), 'Introduction', The Social Shaping of Technology, Milton Keynes: Open University Press.

Marangos, J. (2004), Alternative Economic Models of Transition, Aldershot: Ashgate.

Marshall, A. (1920), Principles of Economics, 8th edn, London: Macmillan.

Minsky, H.P. (1982) Can 'It' Happen Again?, Armonk, NY: M.E. Sharpe.

Myrdal, G. (1957), Economic Theory and Underdeveloped Regions, London: Methuen.

Nelson, R.R. (1987), Understanding Technical Change as an Evolutionary Process, Amsterdam: North-Holland.

Nelson, R.R. and S.G. Winter (1982), An Evolutionary Theory of Economic Change, Cambridge, MA: Harvard University Press.

Parker, R. (2005), John Kenneth Galbraith: His Life, His Politics, His Economics, Toronto: HarperCollins.

Penrose, E. (1959), The Theory of the Growth of the Firm, Oxford: Basil Blackwell. 
Reynolds, P.D., W.D. Bygrave, E. Autio and M. Hay (2002), Global Entrepreneurship Monitor - Summary Report, Kansas City: Ewing Kauffman Foundation.

Rip, A. and R. Kemp (1998), 'Technological change', in S. Rayner and E.L. Malone (eds), Human Choice and Climate Change, Volume 2: Resources and Technology, Columbus, OH: Battelle Press, pp. 327-99.

Robinson, J. (1933), The Economics of Imperfect Competition, London: Macmillan.

Rosenberg, N. (1982), Inside the Black Box, Cambridge: Cambridge University Press.

Rosser, J.B. Jr. (1999), 'On the complexities of complex economic dynamics', Journal of Economic Perspectives, 13 (4), 288-302.

Schumpeter, J.A. (1934), The Theory of Economic Development, original German version published 1911, Cambridge, MA: Harvard University Press.

Schumpeter, J. (1939), Business Cycles: A Theoretical, Historical and Statistical Analysis of the Capitalist Process, 2 volumes, New York: McGraw-Hill.

Schumpeter, J.A. (1942), Capitalism, Socialism and Democracy, New York: Harper \& Row.

Sraffa, P. (1926), 'The laws of returns under competitive conditions', Economic Journal, 36, 535-50.

Steindl, J. (1976), Maturity and Stagnation in American Capitalism, reprint with new introduction by author, New York, Monthly Review Press.

Stilwell, F. (2002), Political Economy: The Contest of Economic Ideas, Oxford: Oxford University Press.

Sundbo, J. (1998), The Theory of Innovation: Entrepreneurs, Technology and Strategy, Cheltenham, UK and Lyme, USA: Edward Elgar.

Sylos-Labini, Paolo (1962), Oligopoly and Technical Progress, Cambridge, MA: Harvard University Press.

Teece, D.J., G. Pisano and A. Shuen (1997), 'Dynamic capabilities and strategic management', Strategic Management Journal, 18, 509-33, reprinted in M.L. Tushman and P. Anderson (2004) (eds), Managing Strategic Innovation and Change: A Collection of Readings, 2nd edn, Oxford: Oxford University Press, pp. 308-32.

Toivanen, O., P. Stoneman and P. Diederen (1999), 'Uncertainty, macroeconomic volatility and investment in new technology', in C. Driver and P. Temple (eds), Investment, Growth and Employment: Perspectives for Policy, London and New York: Routledge.

Tushman, M.L. and P. Anderson (2004), Managing Strategic Innovation and Change: A Collection of Readings, 2nd edn, New York: Oxford University Press.

Von Hippel, E. (1988), Sources of Innovation, Oxford: Oxford University Press. 